\title{
Enterprise Strategy Analysis Based on SWOT Analysis
}

\author{
Jiaxing Weng ${ }^{a}$ and Tingze Liu $^{b}$ \\ School of Management, China University of Mining and Technology (Beijing), Beijing 100083, \\ China. \\ a18811773882@163.com, bessence_life@163.com
}

Keywords: SWOT Analysis, Strategic Management, Internal Environment.

\begin{abstract}
With the rapid development of the economy and the continuous deepening of social reforms, enterprises have unprecedented opportunities for development. However, due to the increasing frequency of international exchanges, the competitiveness of the current social market economy is becoming increasingly fierce. If the enterprises want to have an advantage in the market competition, they must constantly increase their core competitiveness, establish a market strategy and achieve their own in-depth reforms in marketing. SWOT analysis can help companies, organizations or certain system to see their strengths, weaknesses, opportunities and threats, and provide reference for their own effective adjustment of resources and positioning, so as to scientifically and reasonably derive the development strategies that are suitable for itself in the current environment. This paper uses the SWOT model to analyze the advantages and disadvantages of the research objective as well as external opportunities and threats. Through the analysis results, we derive the development strategy that is suitable for the research objective, and then integrate advantages and avoid disadvantages to achieve mutual understanding and self-development.
\end{abstract}

\section{Introduction}

The development and expansion of a company and the enduring success of the company are the result of the company's ability to keep pace with the times in its development. In the history of the world, it is very rare to maintain a competitive advantage and become a long-lived company. Statistics indicate that the average life expectancy of multinational corporations is 40 to 50 years, and that of private enterprises in China is generally 5 to 10 years.[1] Facing with today's increasingly dynamic and competitive situation, it is significant for modern organizations to make long-term strategies.[2]If an enterprise wants to maintain its competitive advantage in the flood of the market economy and quickly adapt to environmental changes, it must adjust its own development strategy in a timely and effective manner according to the environment. The correct corporate development strategy plays a decisive role in the development of a company. The strategic management of enterprises is mainly to put the interests in the future development stage. This is the most scientific development measure. In the process of management, enterprises should attach importance to the development of the real society, optimize the strategic management model, and pay attention to the combination of internal and external environment in order to seek survival and development.

\section{Strategic Management}

Enterprise strategy refers to the long-term and overall plan and scheme for the survival and development of enterprises in the context of intense market competition environment, on the basis of summing up historical experiences, investigating the status quo, and predicting the future. [3] Professor Michael Porter of Harvard University is a typical representative of the traditional definition of enterprise strategy. He argues that "Strategy is the combination of some of the endpoints that companies struggle for and the way companies seek to achieve them." [4] Strategy can be defined as establishing the fundamental long-term goals and taking necessary action sequences and resource allocations to achieve the goals. Strategy is a general direction, a master plan for where the organization is going and how it will develop. When developing the strategy of management science 
and seeking competitive advantage, enterprises often need to understand and grasp the competitive characteristics of external market economy.

Professor Mintzberg, managing professor at McGill University in Canada, analyzed the definition of corporate strategy from five perspectives: plan, ploy, pattern, position, perspective, which constitutes the 5P definition of company strategy. Corporate strategy is the planning and design of the company's future business direction and objectives. It is a universal, comprehensive and authoritative management decision. Market research has found that enterprises have accurate forecasts of industry development trends and appropriate allocation of resources such as people, finances, and materials at various strategic stages. The formulated strategy can guide the healthy and rapid development of the company. Strategic management has played a significant role in improving the company's overall performance. In industries where competition is fiercer, the number of companies that use strategic management is also increasing. The larger the company is, the more importance it is on strategic management. When the company is experiencing rapid changes in the external environment or facing a major turnaround, companies are likely to restructure their strategies.

\section{SWOT Analysis}

SWOT is a classical method adopted by the Harvard Business School in the United States. It is a kind of comprehensive evaluation of internal factors and external factors of the enterprise to evaluate the system and select the best business strategy. SWOT is composed of the first letter abbreviation of Strength, Weakness, Opportunity, Threat. It is a commonly used analysis method for enterprises to formulate development strategies, goals and directions. This theory can effectively analyze its advantages and disadvantages and define its own opportunities and challenges. Using SWOT analysis can help to centralize advantageous resources and capabilities and make them more competitive.

"S" refers to Strength, which refers to an enterprise's own advantages, its own foundation, and its advantages and strengths compared with other industries in the same industry. Only by understanding the capabilities and advantages of the company itself, can we use its own advantages to develop and receive good results. For example, the time-honored name of a century-old company is an advantage compared to emerging companies. Or the geographical location of the company is convenient for transportation and it is also its own advantage. As enterprises expand their development and formulate further development goals and strategies, the "S" is also the first self-examination that must be carried out.

"W" is Weakness. A company's own development must not only understand its own advantages, but also define its own deficiencies. To make up for their own shortcomings and avoid weaknesses is the premise to use their own advantages. For example, the company's weak production capacity, the company's funds are not strong enough, the company's market is not wide enough, etc. are their own deficiencies. When formulating strategies and goals, enterprises should consider the idea of seeking truth from facts, think about ways to improve themselves, and develop steadily.

"O" is the abbreviation for Opportunity. The development of enterprises requires opportunities. It is necessary to look for opportunities, grasp the pulse of the market, changes in people's lifestyles, changes in social needs, and so on. Only by grasping market changes and conforming to the trend of the times can we make breakthroughs and achieve better development.

"T" is the abbreviation for Threat, referring to the challenges and external unfavorable factors. Enterprises must grasp the opportunities in order to better develop and avoid risks.

The SWOT analysis method uses the "S" and "W" to examine the interior of the company itself. "O" and "T" belong to the company's external environment and are an analysis of the company's external environment. If an enterprise wants to achieve rapid and stable long-term development, it must be integrated internally and externally. Companies need to understand all internal and external factors. Only in this way can the corporate strategy not fail and the development of the company can be stable. 


\section{Strategic Analysis of Laundry Retail Stores}

The dry-cleaning industry in China is an imported product. As of December 31, 2016, the number of physical stores in the national dry-cleaning industry is about 1 million. The total volume of the two cities in Shanghai and Beijing is far higher than that of other cities and even some provinces. The situation is obviously non-uniform, but it is undeniable that the dry-cleaning market in Beijing and Shanghai has become saturated. With the increasing demand from the public for the laundry, a large number of private dry-cleaners are transferring. Although the dry-cleaning industry is hot and a large number of investors are eager to get a share, the business level of the dry-cleaning industry is actually mixed. With the huge number of dry-cleaners, the actual dry-cleaning physical stores that can provide professional technology account for only $20 \%$ of the total. The low threshold for investment dry cleaners has attracted many investors who do not have experience in technology to join in, but the level of service they provide cannot meet the growing demand for care of customers, and it eventually becomes the result of the transfer.

For the special group of teachers and students in colleges and universities, in addition to the basic laundry needs, there are some new requirements unique to this group. For example, due to academic time schedules, students will have some problems with time coordination. Or some expensive special fabrics can't be washed by themselves. This group presents new opportunities for college laundry because of its special environment, and it also creates new challenges.

Through SWOT analysis to analyze the internal environment of university laundry, the following table is obtained:

Table 1. SWOT Analysis of the Laundry in Colleges and Universities

\begin{tabular}{|c|c|}
\hline $\begin{array}{c}\text { Strength: } \\
\text { Comprehensive online and offline marketing by using } \\
\text { the Internet. } \\
\text { Collaborate with college students' entrepreneurial } \\
\text { projects to promote closeness. }\end{array}$ & $\begin{array}{c}\text { Weakness: } \\
\text { Internal managers are inexperienced. } \\
\text { Network marketing also needs to perfect } \\
\text { the space. } \\
\text { The scope and scale of business are } \\
\text { limited. }\end{array}$ \\
\hline $\begin{array}{c}\text { Opportunity: } \\
\text { The market demand is big in the campus intensive area. } \\
\text { The state and schools offer preferential policies for } \\
\text { college students. }\end{array}$ & $\begin{array}{c}\text { Threat: } \\
\text { Competition from existing laundries is } \\
\text { intense. } \\
\text { The depreciation cost of rent and fixed } \\
\text { assets is high. }\end{array}$ \\
\hline
\end{tabular}

According to the above analysis of all aspects of the laundry, in the selection strategy, the relevant diversification strategy and non-related diversification strategy can be selected.

With the development of enterprises and the accumulation of capital, relevant businesses, such as suit rental, are gradually carried out, and the business scope of enterprises is exaggerated to diversify business risks, which is a related diversification strategy.

When the laundry industry market is saturated, it can gradually develop into other industries, diversify business risks and improve corporate profitability. This is a non-related diversification strategy.

\section{Summary}

As the Internet changes economic environment and changes human civilization, the competition rules of enterprises have been changing. The theory of corporate strategic management needs to be constantly improved and enriched in the new era. [5] Any enterprise is a very complex integrated entity. The environment and its own conditions that it faces are constantly changing. Therefore, it must be advancing with the times and seeking truth from facts when formulating corporate strategies. The SWOT analysis method is effective for the analysis of enterprises and the formulation of goals, and specific applications need to be flexible and changeable. Of course, the SWOT analysis method alone is only the first step toward advancing with the times. It is also difficult to make the company's development lasting. It also requires companies to position their strategic goals for development, analyze and construct their own strategic space. 


\section{References}

[1]. Chan, S. L., 2000, Information technology in business processes[J]. Business Process Management Journal, 6(3), 224-237.

[2]. McCutcheon, D. M., and Meredith, J. R., 1993, Conducing case study research in operations management[J]. Journal of Operations Management, 11, 239-256.

[3]. Meredith, J. R., 2001, Hopes for the future of operations management[J]. Journal of Management, 19, 397-402.

[4]. Campbell A, Gold M., Alexander M. Corporate strategy: the quest for parenting advantage [J]. Harvard Business Review,1995,73(2):120 132.

[5]. P. K. Chintagunta, S. Gopinath, S. Venkataraman, The effects of online user reviews on movie box-office performance: Account for sequential rollout and aggregation across local markets[J], Marketing Science 29(5) (2010)944-957.

[6]. O. Netzer, R. Feldman, J. Goldenberg, M. Fresko, Mine your own business: Market structure surveillance through text mining[J], Marketing Science,31(3) (2012)521-543.

[7]. P. A. Pavlou, A. Dimoka, The Nature and Role of Feedback Text Comments in Online Marketplaces: Implications for trust building, price premiums, and seller differentiation[J]. Information Systems Research, 17(4)(2006)392-414.

[8]. Eijkman’s, C, Kirchhoff, P., Beukeboom, C. J. (2015). A stage to engage:social media use and corporate reputation[J]. Tourism Management, 47, 58-67.

[9]. Flanagan, A. J., Metzger, M. J. (2013). Trusting expert-versus user-generated ratings online:the role of information volume, valencce, and consumer characteristics[J]. Computers in Human Behavior, 29(4), 1626-1634. 